\title{
Comparative Analysis of Mental Expenses for End-Level Students in Dealing with Online and Direct Learning with the NASA-TLX Method
}

\author{
Fadilla Nur Afifah*, Sekarlintang, Natasha Elvina Dwi Putri, Deifa Aulya and Didit Damur \\ Rochman
}

Department of Industrial Engineering, Faculty of Engineering, Widyatama University, Bandung City, West Java, Indonesia

*fadilla.nur@widyatama.ac.id

Article History: Received:11 January 2021; Accepted: 27 February 2021; Published online: 5 April 2021

\begin{abstract}
Limitation of direct physical interaction related to the Covid-19 pandemic has an impact on the education sector, where all learning activities are carried out online to limit physical interactions. Online learning methods are considered more flexible to do when compared to direct learning methods. This research was conducted to determine how much difference the mental load felt by final year students in online learning and direct learning. Measurement of a mental load was carried out using the National Aeronautics and Space Administration Task Load Index (NASA-TLX) method by distributing questionnaires containing six subscales of mental load measurement to final year students of four different study programs, including Management, Accounting, Informatics Engineering, and English. The six subscales used include Mental Demands, Physical Demands, Temporal Demands, Own Performance, Effort, and Frustration. Based on the results of the average calculation of the four sample groups, it shows that the mental load of online learning is $0.4 \%$ greater than direct learning, $81.3 \%$ and $80.9 \%$, respectively.
\end{abstract}

Keywords: NASA-TLX, mental workload, online learning

\section{Introduction}

Online learning methods have begun to be widely applied since the beginning of 2020, this is done to limit physical contact between individuals related to the Covid-19 pandemic. Students carry out independent learning activities using the learning materials provided or make use of information sources available online. The existence of new methods that are enforced is also supported by technological developments that are considered capable of supporting learning activities, the availability of widespread information, the easy provision of teaching materials, and the availability of live streaming and video conferencing support applications that facilitate face-to-face processes are considered sufficient to carry out the activity process.

Online learning methods are considered more flexible because they can make it easier for students to carry out learning activities anywhere and anytime, while direct learning is carried out according to a predetermined time and place. The two methods have their respective advantages and disadvantages, although online learning is considered more flexible, direct learning activities have a clearer path because they are carried out directly in communicating, the direct learning method also tends to be less dependent on technology because it does not require an internet network in the learning process.

The difference in method that is considered quite significant results in different mental workloads because they have different working conditions. Mental Workload according to Meshkati in Astianto and Suprihhadi (2014) can be defined as a difference between the capacity or ability of workers and the job demands that must be faced. Two factors can affect mental workload, namely internal factors, and external factors. Internal factors are factors resulting from workload reactions arising from within the body, internal factors include gender, age, satisfaction, motivation, and health status, while external factors are work environment, responsibilities, and work schedule.

The high-intensity level of psychological workload (mental) will cause psychological fatigue, which is accompanied by the appearance of feelings of fatigue, fatigue, lethargy, and reduced alertness (Simanjuntak \& Situmorang, 2010). The emergence of feelings of fatigue, fatigue, lethargy, and reduced alertness can also affect the learning process and results, learning activities are not optimal and this is certainly not good for final year students who will compile the final project. This research was conducted to be able to find out how much difference the mental load felt by final year students when doing online learning and direct learning.

\section{Literature Review}




\subsection{Mental workload}

In workload, there are three contexts, namely prediction of workload, assessment of workload caused by tools, and workload experienced by a person. Meanwhile, according to mental workload, it is the degree of process capacity that is expended during performing tasks and the concept of mental workload will appear due to information processing (Wickens \& Holland, 2000). Information processing involves the perception, interpretation, and processing of information conveyed by the sensory organs. From all these opinions it appears that mental workload exists in every type of work caused by information processing. Today there is still a separation between manual labor and brain work, but now this line is starting to thin. Manual work also began to involve mental activities, namely supervisory tasks, information processing.

\subsection{Learning fatigue factors}

Fatigue is a process that can result in a decrease in welfare, capacity, or performance as a result of work activities (Nurmianto, 1996). Fatigue is a condition when a person feels physically or mentally tired, which can be caused by:

a) Long study hours without intervening rest or recovery periods

b) Strong and sustainable physical activity

c) Strong and sustainable mental effort

d) Working during some or all of the natural time to sleep (as a result of shifts or working for long periods)

e) Inadequate sleep and rest

\subsection{Rating}

In giving the rating, respondents are asked to fill in a rating based on the comparison of conditions between direct learning and distance learning. Charging is done by paying attention to the rating on the six mental load indicators. The descriptions of the six ratings are in the table below.

Table 1. NASA-TLX indicator rating

\begin{tabular}{|c|c|c|}
\hline Scale & Rating & Description \\
\hline Mental Needs & $\begin{array}{l}\text { Low - High } \\
\quad(\mathrm{O}-100)\end{array}$ & $\begin{array}{c}\text { Knowing the amount of mental activity } \\
\text { needed to complete a task }\end{array}$ \\
\hline Physical Needs & $\begin{array}{l}\text { Low - High } \\
\quad(\mathrm{O}-1 \mathrm{OO})\end{array}$ & $\begin{array}{c}\text { Knowing the amount of physical activity } \\
\text { needed to complete the task }\end{array}$ \\
\hline Time Needs & $\begin{array}{l}\text { Low - High } \\
\text { (O-100) }\end{array}$ & $\begin{array}{l}\text { Knowing the many pressures felt in } \\
\text { completing the task }\end{array}$ \\
\hline Perfomance & $\begin{array}{l}\text { Low - High } \\
\quad(\mathrm{O}-10 \mathrm{O})\end{array}$ & $\begin{array}{c}\text { Knowing the success rate in completion } \\
\text { of tasks }\end{array}$ \\
\hline Business Rate & $\begin{array}{l}\text { Low - High } \\
\quad(\mathrm{O}-100)\end{array}$ & $\begin{array}{c}\text { Knowing the amount of mental and } \\
\text { physical activity required in completing } \\
\text { tasks }\end{array}$ \\
\hline Frustrating Level & $\begin{array}{l}\text { Low - High } \\
\text { (O-100) }\end{array}$ & $\begin{array}{l}\text { Knowing the amount of anxiety, stress, } \\
\text { stress and panic in completing the task }\end{array}$ \\
\hline
\end{tabular}

The following is an explanation of the six indicators on the rating, with the lowest scale being 0 and the highest being 100. Description of the six indicators.

Table 2. Description of six NASA-TLX indicators 
Comparative Analysis of Mental Expenses for End-Level Students in Dealing with Online and Direct Learning with the NASA-TLX Method

\begin{tabular}{|l|lr|}
\hline \multicolumn{1}{|c|}{ Question } & & Scale \\
& & High \\
\hline $\begin{array}{l}\text { 1. Mental needs (MN) } \\
\text { The mental effort you need to complete your } \\
\text { assignment? }\end{array}$ & $\begin{array}{l}\text { Low } \\
\text { Your value: }\end{array}$ & High \\
\hline $\begin{array}{l}\text { 2. physical needs (PN) } \\
\text { The physical effort you need to complete your } \\
\text { task? }\end{array}$ & Low & 100 \\
\hline 3. need of time (NT) & Your value: & High \\
$\begin{array}{l}\text { Pressure do you feel about time to do your } \\
\text { job? }\end{array}$ & Low & 100 \\
\hline $\begin{array}{l}\text { 4. Performance (P) } \\
\text { your level of success in doing your job? }\end{array}$ & Your value: & High \\
& Your value: & 100 \\
\hline $\begin{array}{l}\text { 5. frustration level (FL) } \\
\text { Anxiety, stress, and stress do you feel doing } \\
\text { your iob? }\end{array}$ & Low & High \\
\hline $\begin{array}{l}\text { 6. Effort Level (EL) } \\
\text { The physical and mental work you need to } \\
\text { complete your assignment? }\end{array}$ & Your value: & 100 \\
\hline
\end{tabular}

There are several steps described by Hancock and Meshkati (1988) in using the NASA-TLX method namely:

1. Explanation of mental load indicators to be measured

2. Weighting

3. Rating

4. Count products

Product $=$ rating $x$ factor weight

5. Calculating Weighted Workload (WWL)

$\mathrm{WWL}=\sum$ Product

6. Calculating mental load scores

score $=\sum($ weight $\times$ rating $) 15$

7. Interpretation of the scores

\subsection{Questionnaire}

A questionnaire is a tool for primary data collection with a survey method to obtain respondents' opinions. Questionnaires can be made to respondents by (1) Sent via computer, for example, electronic mail (e-mail); (2) Sent by post (mail questionnaire); (3). Directly by the researcher (independently). The questionnaire is usually sent directly by the researcher if the respondents are relatively close and the distribution is not too broad. By post or e-mail allows low costs, wider coverage of respondents, and fast time. There is no specific principle in the questionnaire but researchers can consider its effectiveness and efficiency in terms of being sent by post, e-mail, or directly from researchers.

\subsection{NASA-TLX}

NASA-TLX is a multidimensional rating method used to measure the overall mental workload based on the average weights of the 6 subscales, namely Mental Demands, Physical Demands, Temporal Demands, Own Performance, Effort, and Frustration (NASA Performance Research Group, 1988). Meanwhile, according to Rubio et al. (2004), this method has a good level of sensitivity because the measurement is reviewed from 6 subscales and is comprehensive.

\section{Research Methodology}




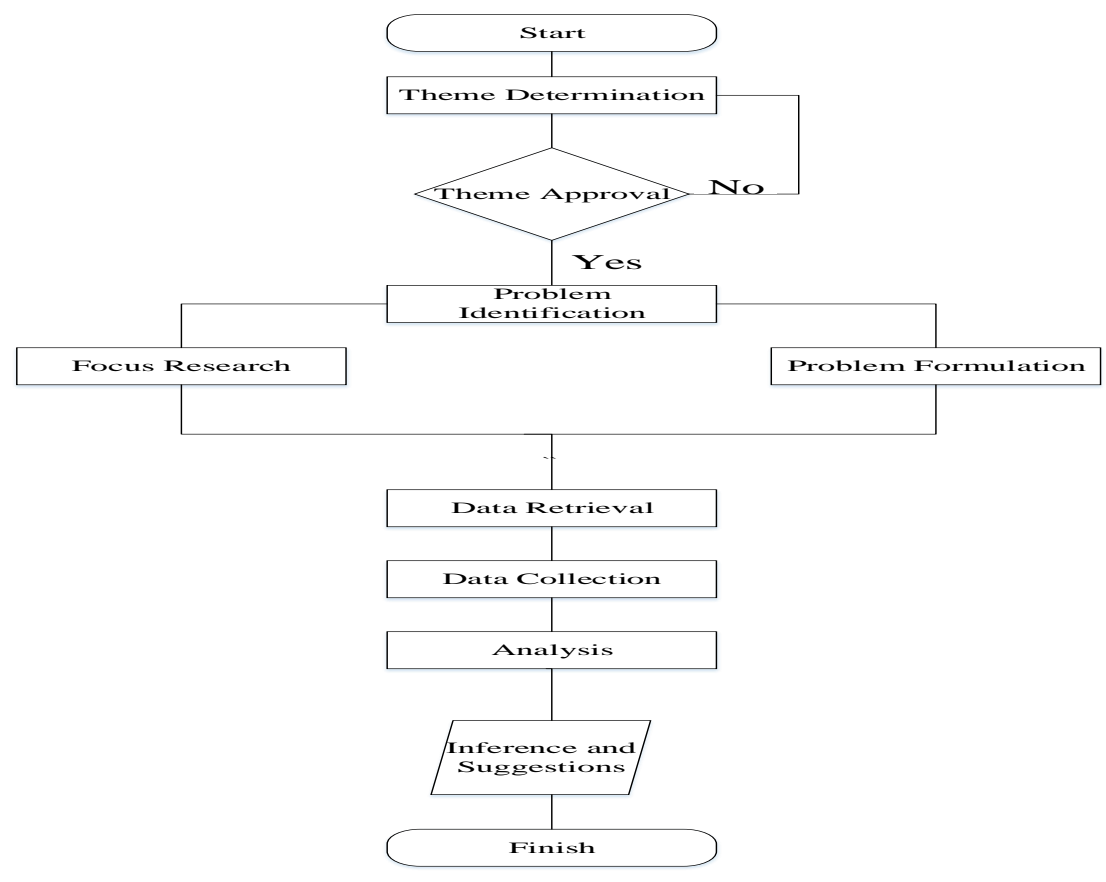

The research methodology is described in the following stages:

1. The stages of determining the theme: this stage is the process of determining the theme of research to be carried out. The process of determining the theme of this research involves the data to be studied and the methods used. The theme chosen is workload analysis using the NASA-TLX method.

2. Problem identification stage: this stage is the stage of identifying problems with the Covid-19 pandemic conditions that affect lectures for final year students. This study analyzes the causes of mental load experienced by final year students based on a questionnaire that has been made.

3. Focus Research stages: this stage is the stage of limiting the problems contained in this research, namely the scope of this research only includes final students majoring in informatics engineering, English, management, and accounting at Widyatama University.

4. Stages of problem formulation: this stage is the stage of problem formulation in this study, namely "How to compare the mental load conditions experienced by final year students during distance learning and direct learning?".

5. Data collection stage: this stage is the stage of identifying problems related to mental load. The data taken are mental needs, physical needs, time needs, performance, level of effort, and level of frustration. Retrieval of data using primary data in the form of filling out questionnaires to respondents. Respondents needed for data collection were 60 people, each from different majors, namely: informatics engineering, English, management, and accounting. The data processed were 12 people from each department who were taken randomly. Data collection stages: this stage is carried out to understand the theories used in research, such as the theory of mental load, factors

6. Data processing stages: this stage is the stage of determining a scale that will affect the conclusion of the mental load experienced by final year students at Widyatama University.

7. Analysis stage: this stage is the stage of distinguishing the results obtained from calculating metal loads before distance learning and after distance learning.

8. The stages of drawing conclusions and suggestions: this stage is carried out after the analysis stage, drawing conclusions containing the results of the research conducted. Suggestions in this study are aimed at developing further research and improvements in distance learning systems and direct learning.

\section{Results and Discussion}

The results of data collection through a questionnaire addressed to the final year students of four different study programs are then processed into a percentage of mental load. The average mental load conditions are presented in the following table:

Table 3. Average calculation NASA-TLX. 


\begin{tabular}{|c|c|c|}
\hline \multicolumn{3}{|c|}{ Average } \\
\hline Description & Online & Direct \\
\hline Sampel Group 1 & $77,4 \%$ & $81,5 \%$ \\
\hline Sampel Group 2 & $84,0 \%$ & $81,9 \%$ \\
\hline Sampel Group 3 & $79,6 \%$ & $80,5 \%$ \\
\hline Sampel Group 4 & $84,0 \%$ & $79,7 \%$ \\
\hline Average & $81,3 \%$ & $80,9 \%$ \\
\hline
\end{tabular}

In the table of the average percentage of mental load above, the four sample groups show different percentage levels, the sample groups 1 and 3 show that direct learning has a higher mental load with a percentage of $81.5 \%$ and $80.5 \%$ compared with online learning, while the sample groups 2 and 4 show that online learning has a higher mental load with a presentation of $84 \%$ compared to direct learning.

Sample group 1 and sample group 3 showed a greater direct learning mental load, this is because the average value of all subscales for calculating the mental load of sample group 1 and sample group 3 was greater direct learning, which means that in the sample group 1 and sample group 3 requires a greater effort at the time of hands-on learning. Based on the data collection obtained in the sample group, it is known that the highest mental load subscale presentation is the level of effort with an assessment rating of 95 , this shows the amount of physical and mental activity needed to carry out learning activities in the sample group 1 and sample group 3 .

The data listed in the table are then presented in two graphs that can show the differences in mental load conditions felt by each student. The data listed in the table are then presented in two graphs that can show the differences in mental load conditions felt by each student.

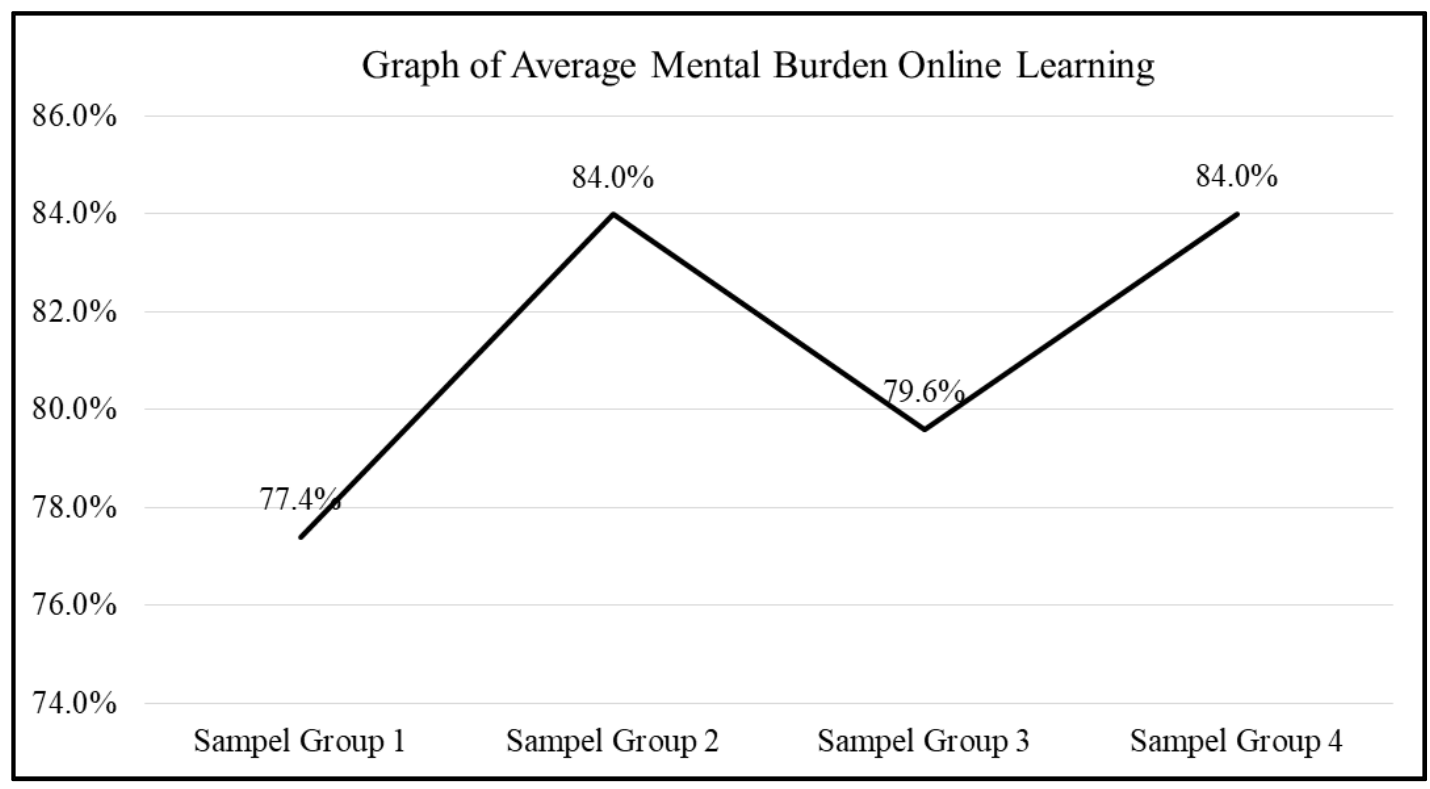

Figure 1. Graph of average mental load condition 1 


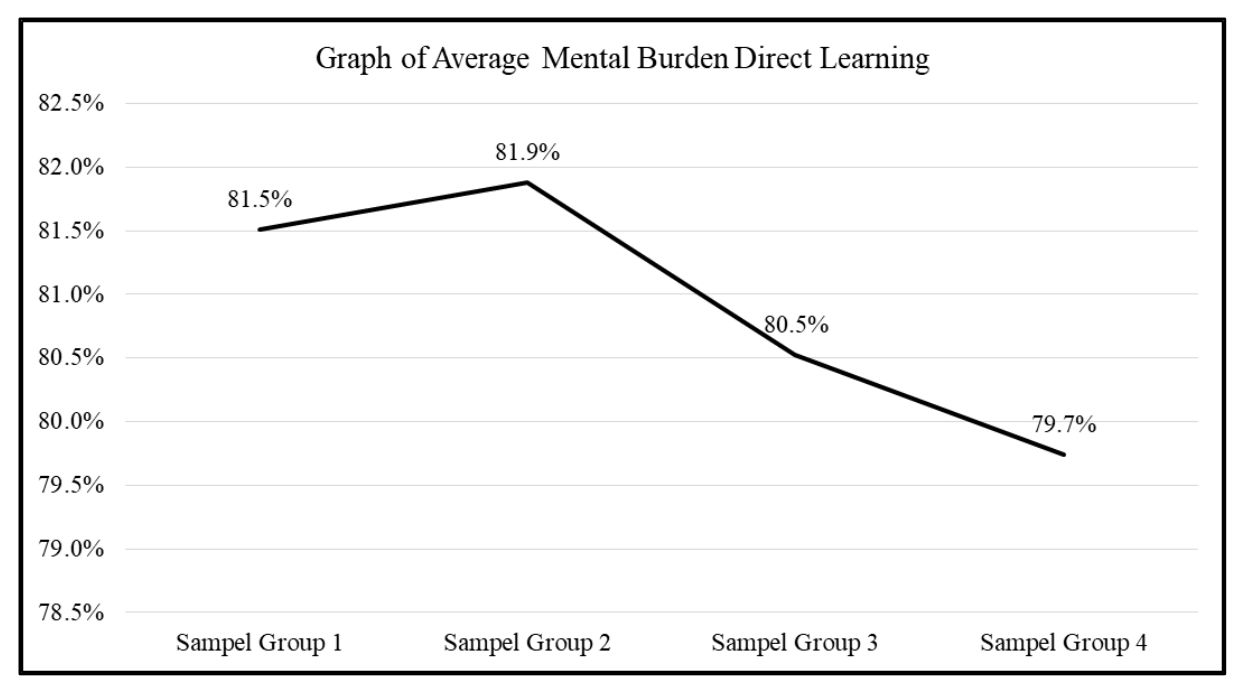

Figure 2. Graph of average mental load condition 2

The two graphs show that the mental load conditions experienced by each student are different. Figure 1 shows the value of mental load experienced by the four Sample Groups while doing Distance Learning. Sample Group 2 and Sample Group 4 have the highest mental load conditions. This is influenced by the total weight of each indicator. In Sample Group 2 and Sample Group 4, the NASA-TLX indicator that has the highest weight is in the Frustration Level category, meaning that during the distance learning process students require great physical and mental activity in completing tasks so that the mental load conditions experienced by students in Sample Group 2 is quite high at $84 \%$.

Figure 2 shows the value of the mental load experienced by the four Sample Groups when doing direct learning. The mental load conditions in Sample Group 1 and Sample Group 2 showed quite high results, with a value of $81.5 \%$ and $81.9 \%$, both of which had differences that were not much different. In Sample Group 1 the NASA-TLX indicator which has the highest weight is in the Frustration Level category and in Sample Group 2 the NASA-TLX indicator which has the highest weight is in the Effort category which means when doing direct learning the conditions experienced by the second Sample Group are the emergence anxiety, stress, and panic in completing tasks.

\section{Conclusion}

The results obtained from the calculation of mental load using the NASA-TLX method are the average mental load experienced by final year students during online learning and direct learning, where the mental load online learning shows the highest average is $84 \%$, with an overall average is $81.3 \%$, while the mental load of learning directly shows the highest average is $81.9 \%$ with an overall average is $80.9 \%$. The difference of $0,4 \%$ in the percentage of the mental load indicates that the mental load experienced by final year students is greater when learning online than during direct learning. The suggestions in this study are for further research it is recommended to take more data and a wider scope to maximize results.

\section{References}

1. Astianto, A., \& Suprihhadi, H. (2014). Pengaruh Stres Kerja dan Beban Kerja Terhadap Kinerja Karyawan PDAM Surabaya. Jurnal Ilmu \& Riset Manajemen, 3(7), 1-17.

2. Simanjuntak, R. A., \& Situmorang, D. A. (2010). Analisis Pengaruh Shift Kerja terhadap Beban Kerja Mental dengan Metode Subjective Workload Assessment Technique (SWAT). Jurnal Teknologi, 3(1), 53-60.

3. Koesomowidjojo, S. R. (2017). Panduan praktis menyusun analisis beban kerja. Jakarta: Raih Asa Sukses.

4. Hancock, P. A., \& Meshkati, N. (1988). Human mental workload. Amsterdam: North-Holland.

5. Wickens, C. D., Hollands, J. G., Banbury, S., \& Parasuraman, R. (2015). Engineering Psychology and Human Performance. New Jersey: Prentice-Hall.

6. Kroemer, H., \& Grandjean, E. (2000). Fitting the task to the man. London: Taylor \& Francis.

7. Rubio, S., Díaz, E., Martín, J., \& Puente, J. M. (2004). Evaluation of subjective mental workload: A comparison of SWAT, NASA-TLX, and workload profile methods. Applied Psychology, 53(1), 61-86. 
Comparative Analysis of Mental Expenses for End-Level Students in Dealing with Online and Direct Learning with the NASA-TLX Method

8. Ramadhan, R., Tama, I. P., \& Efranto, R. Y. (2014). Analisa Beban Kerja dengan Menggunakan Work Sampling dan NASA-TLX Untuk Menentukan Jumlah Operator (Studi Kasus: PT XYZ). Jurnal Rekayasa dan Manajemen Sistem Industri, 2(5), 926-973.

9. Pujihastuti, I. (2010). Prinsip penulisan kuesioner penelitian. CEFARS: Jurnal Agribisnis dan Pengembangan Wilayah, 2(1), 43-56.

10. Nurmianto, E. (996). Ergonomi Konsep Dasar dan Aplikasinya. Surabaya: ITS. 